\title{
The historical development of the housing policy of Russian cities from pre-industrialization period to free real estate market
}

\section{Olga Siegmunt}

To cite this article: Olga Siegmunt (2019): The historical development of the housing policy of Russian cities from pre-industrialization period to free real estate market, Planning Perspectives, DOI: $10.1080 / 02665433.2019 .1642236$

To link to this article: https://doi.org/10.1080/02665433.2019.1642236

Published online: 17 Jul 2019.

Submit your article to this journal ऍ

山 Article views: 8

View Crossmark data $\complement$ 


\title{
The historical development of the housing policy of Russian cities from pre-industrialization period to free real estate market
}

\author{
Olga Siegmunt ${ }^{\mathrm{a}, \mathrm{b}}$ \\ ${ }^{a}$ Department of Deviantology and Criminology, Law Institute, Siberian Federal University, Krasnoyarsk, Russia; \\ ${ }^{\mathrm{b}}$ Department of Educational and Social Sciences, University of Vechta, Vechta, Germany
}

\begin{abstract}
This article focuses on long-term housing policy in Russia (1917 onwards). In view of the fact that during the Soviet era housing policy was set by the head of state, the article will discuss the following four periods: preindustrialization, from industrialization to the Stalin era, from the Khrushchev era to developed Socialism, and post-Soviet collapse. The historical analysis of Soviet housing policy begins with the pre-industrialization period when significant political decisions were taken. A systematic and chronological description of normative legal documents then introduces the reader to the topic and gives a basic knowledge of the physical and social structure of the society. In the next part of this article, the main tendencies in housing policy up until the beginning of the 1950s are then described. Both the preindustrial period and the period into the 1950s constitute the characteristics of a housing policy that was sustained until the end of the Soviet period.
\end{abstract}

\section{KEYWORDS}

City development; housing policy; segregation; industrialization; migration; Russia

\section{Introduction}

The rationale underpinning this article originated from the need to interpret the results of a previous study of neighbourhoods in Russian cities. ${ }^{1}$ The goal of this study is to analyze the ecological effects of neighbourhoods on the basis of the social disorganization theory by Shaw and McKay. ${ }^{2}$ In contrast to the theoretical assumptions, social cohesion in neighbourhoods was higher when the socio-economic status of the neighbourhoods was low. Another result was that ethnic heterogeneity had no effect on the neighbourhood level at all.

However, social disorganization theory is based originally on the observations of the developing processes of American cities in the 1920s. In general, capitalistic cities were developed in the context of the free market during quasi-natural segregation processes. Social groups were segregated in Chicago and in other American cities in the 1920s by market mechanisms: rental and sale prices for real estate were lower in the so-called transition zones near the industrial areas and higher on the suburbs. The financial situation of most immigrants was poor and they were forced to stay initially in the transition zones. If their socio-economic status improved, they moved to the suburbs. ${ }^{3}$

Soviet cities were divided into functional zones too. Their development was subject to strict planning processes and an assumption about the equality of all inhabitants. Self-selection was almost

CONTACT Olga Siegmunt olga.siegmunt@uni-hamburg.de

${ }^{1}$ Siegmunt, Selbstkontrolle; Siegmunt, Neighborhood Disorganization; Siegmunt, "Mediating Role."

${ }^{2}$ Shaw and McKay, Juvenile Delinquency.

${ }^{3}$ Park, The city; Park and Burgess, "Introduction"; Park et al., The City; Shaw and McKay, "Juvenile Delinquency."

(c) 2019 Informa UK Limited, trading as Taylor \& Francis Group 
impossible and the socialistic society was held together according to the principle of the equality of all citizens. Moreover, the distribution of inhabitants was strictly controlled. For this reason, social homogeneity was low within neighbourhoods and high between neighbourhoods. The homogeneity was probably somewhat higher within neighbourhoods in the central districts because a large portion of the nomenclatura lived there. Nomenklatura was an elite group of people in the former Soviet Union who held influential posts in government, industry and other professional fields which were filled by the Communist Party.

The real estate market was established in Russia first in the 1990s by the process of privatization: families had the opportunity to buy the apartments in which they lived, to sell their property, and to move to new residences. Emergent new quasi-natural segregation processes were correlated to the socio-economic inequality of inhabitants. It led to increasing inequalities between neighbourhoods. This processes can be compared with the 'laissez-faire model of society used to describe Chicago in the 1920s'.

Segregation in American cities in the 1920s was concurrent with rapid urban growth and significant waves of migration. In contrast, segregation processes in modern Russia have occured in the context of a social collapse and during stagnating urbanization.

Soviet planners point out, for instance, that in capitalist societies urban planning is used to serve the interests of the ruling class, as revealed in a struggle between private and public interests. Private ownership of land and the means of production are major impediments to the planned construction of cities, whilst the spatial distribution of property gives rise to class and racial segregation. ${ }^{5}$

It would be incorrect to claim that Soviet cities are 'fundamentally different' from the capitalist cities. $^{6}$ As Jürgen Friedrichs ${ }^{7}$ says, there are no specific socialist types of land use, processes of distributing new housing, or for establishing the internal organization of residential blocks, or location of companies. In his opinion, the principal goal of socialist urban planning, namely the settlement of new residential areas near working areas, was also pursued in Western planning. David M. Smith ${ }^{8}$ pointed out, while it may be hard to find evidence of highly distinctive urban and residential forms, but to argue that modern industrial cities are all very much the same is to overlook some special features of those in socialist countries, not least with respect to their general spatial structure.

As a result of specific planning strategies, the population of a Soviet city was, for a long time, heterogeneous within and homogenous between neighbourhoods in their socio-economic composition, because of the lack of self-selection afforded to inhabitants. Residential segregation is characteristic of social inequality. It reflects and result from the composition of the social and demographic groups on the one hand, and the urban structure on the other. Ivan Szelenyi ${ }^{9}$ studied urban social inequalities of the Soviet cities and drew two conclusions: (1) 'housing inequalities are being created now, as those with higher incomes get the better housing' and (2) 'inequalities are being created by administrative allocation, i.e. by the distinctively socialist mechanism which was supposed to replace the capitalist market method of allocation'. ${ }^{10}$

There are some publications in English and Russian about the development of Russian cities during the Soviet time. ${ }^{11}$ The present article focuses on long-term housing policy in Russia beginning

\footnotetext{
${ }^{4}$ Andrusz, "Structural Change," 68.

${ }^{5}$ Andrusz, "Some Key Issues in Soviet Urban Development," 159.

${ }^{6}$ Smith, "The Socialist City," 73.

${ }^{7}$ Friedrichs, "Large Cities."

${ }^{8}$ Smith, "The Socialist City."

${ }^{9}$ Szelenyi, Urban Inequalities.

${ }^{10}$ Ibid., 6.

${ }^{11}$ Andrusz, "Some Key Issues"; Andrusz, "Urban Government"; Andrusz, Housing and Urban Development; Andrusz, "The Built Environment"; Andrusz, "A Note on the Financing"; Andrusz, "Berlin, Moscow, Warsaw"; Bater, "St Petersburg"; Bater, The Soviet Scene;
} 
on the year 1917 and into the modern time. Following periods will be discussed: pre-industrialization, from industrialization to the Stalin era, from the Khrushchev era to developed Socialism, and post-Soviet collapse.

\section{Pre-industrialization housing policies in Soviet cities (1917 to 1928)}

The new housing policy was implemented during 'war communism' between 1918 and 1921. The main trend of this time was that owners lost the rights to own real estate. Only the state had the right to build and own real estate. The latter had already been regulated before 1920 . The housing problem would be solved by requisitioning part of certain property owners' living space for new tenants, generally poor workers and their families. This idea was the beginning of municipal shared apartments known as 'communalca' in Russia. ${ }^{12}$

Three decrees were adopted in these years. One of them regulated the rights to private property for land: the decree 'About the Land' ${ }^{13}$ ordered that the right to private property for land was made null and void permanently. Land could not be sold, bought, rented, mortgaged, or confiscated in any way. All land property was appropriated without compensation, turned into national property and passed into public use. Private ownership of land was finally cancelled by the Constitution ${ }^{14}$ : ' ... the private ownership for land is repealed and total supply of land is declared as public property; it will be the property of workers without redemption ...' (Art. 3a).

The next two laws built the basis for the change of rights to private property for living accommodation. The decree 'About the Prohibition of Real Estate Business ${ }^{15}$ ordered that because of the forthcoming collectivization of urban estates, all businesses with real estate and land in cities and towns, whether selling, buying or mortgaging, etc., would be on hold. People who continued in the real estate business would receive a monetary penalty, from a fine to deprivation of property. The decree 'About the Abolition of the Rights to Private Property for Real Estate in the Cities ${ }^{\text {' }}$ made void the rights to private property for real estate in urban settlements with populations over 10,000 (Art. 2). Only local governments had the right to build in such urban settlements (Art. 6). Former owners of real estate had the same rights as other renters (Art. 10) and the local government could order the same rules for settlements with fewer than 10,000 inhabitants (Art. 20).

The Department of Public Health defined the standards for the size of living area per resident on 17 July 1919 in some temporary rules for the organization of housing accommodation. ${ }^{17}$ According to these rules, an adult person needs a minimum of $30 \mathrm{~m}^{3}$ of air to feel good after a night's sleep. If the air volume is less than this, the person will get a headache after waking up because of the lack of oxygen. This cubic capacity was the basis of calculating the size of living area per person: $8.25 \mathrm{~m}^{2}{ }^{18}$

Bater, Russia and the Post-Soviet; Belkina, "Strategic Plans"; Bessonova et al., "Market Experiment"; Davidow, Cities without Crisis; Gutnov et al., The Ideal Communist City; Hamm, The City; Han-Magomedov, "Architecture of the Soviet Avant-Garde"; Nefedova and Treyvish, "Russian Cities"; Szelenyi, Urban Inequalities, and so on.

${ }^{12}$ Lenin, Complete Edition. Issue 54, 380.

${ }^{13}$ The decree "About the Land" was adopted by the second All-Russian Congress of Councils of Workers and Soldiers Deputies [Dekret II Vserossijskogo s"ezda Sovetov o zemle] from October 26 (November 8), 1917 (Decrees of Soviet Rule).

${ }^{14}$ The Constitution of the RSFSR was passed by the Fifth National Congress of Council of Public Commissars July 10, 1918 [Konstitutciya RSFSR Prinyata V Vserossijskim s"ezdom Sovetov v zasedanii ot 10 iyulya 1918 goda].

${ }^{15}$ The Decree of the Soviet Government "About the prohibition of the real estate business", December 14, 1917 [Dekret SNK RSFSR ot 14.12.1917 O zapreshchnii sdelok s nedvizhimost'yu].

${ }^{16}$ The Decree of the Soviet Government "About the abolition for the rights to private property for real estate in the cities", August 20,1918 [Dekret VCIK ot 20.08.1918 Ob otmene prava chastnoj sobstvennosti na nedvizhimosti v gorodah].

${ }^{17}$ Kashkadamov, Sanitary Control.

${ }^{18}$ Meerovitsch, Punishment by Living Accomodation, 17-8. 
The $8.25 \mathrm{~m}^{2}$ norm was included in the new law ${ }^{19}$ passed the next year. This norm was also the juridical reason for the creation of new municipal shared apartments. There was also a new criteria to settle the population (a biological criterion): how much oxygen a person needs to feel well.

Living houses were also going over to state ownership up until 1921. However, plenty of settlements and factories were destroyed during the Civil War (1918-1922). Construction activity was anarchic $^{20}$ and so the Soviet government implemented a new strategy: the New Economic Policy (NEP). The NEP was an economic policy of Soviet Russia between 1921 and 1928, which replaced the policy of war communism. The NEP was announced for the first time at the 10th Congress of the Russian Communist Party during 8-16 March 1921, in Moscow. The basic points of the NEP were described in the decree of the government 'Instructions of the Soviet Government about the Implementation of the New Economic Policy' from 9 August 1921. The changes give the impression that the main political idea was turning from total state control over real estate to a real estate market with public participation and private ownership.

The Soviet government used the situation and motivated the people to found housing co-operatives. $^{21}$ In contrast to the capitalistic version with private participation, the new form was organized on the basis of public relationships. There were three kinds: housing and rental co-operatives, worker housing and building co-operatives, and common housing and building co-operatives.

The forms of ownership were specified in 1922 by the Civil Code of the Russian Soviet Federative Socialist Republic (RSFSR) ${ }^{22}$ : governmental (nationalized and municipalized), co-operative and private (Art. 52). The land was exclusively in governmental ownership (Art. 53). The non-municipalized buildings could only be in private ownership (Art. 54). The buildings could also be nationalized or municipalized. ${ }^{23}$ Both of them are in the ownership of the state. The nationalized buildings were under the authority of federal public institutions and the municipalized buildings are under the authority of local governments (now federal subjects). From 1921, a private person could build and invest private capital ${ }^{24}$ in it.

In doing so the government supported the establishment of an elite. Some social groups were privileged, e.g. government officials, leaders of the military and navy, and scientists. ${ }^{25}$ They could have additional living space. As a consequence, the new stratification of the system also developed an ethacratic system. ${ }^{26}$ The term ethacratie means governmental power. The social groups differ first by the position in the hierarchy of power, accessible resources, and privileges. The other characteristics, such as affluence or life style, are dependent on the formal position in the hierarchy of power. All other differences, such as demographic, religious or cultural are secondary.

\footnotetext{
${ }^{19}$ Decree of the Soviet Government "About the measures of correct distribution of the living accommodations between workers", May 25 , 1920 [Dekret SNK RSFSR ot 25.05.1920 O merah pravil'nogo raspredeleniya zhilishch sredi trudyashchegosya naseleniya].

${ }^{20}$ Luzenko, Housing Problem, 4.

${ }^{21}$ Decree of the Central Executive Committee of Soviet Union "About housing co-operatives", August 19, 1924 [Postanivlenie CIK SSSR, SNK SSSR ot 19.08.1924 O zhilishchnoj kooperacii].

${ }^{22}$ Civil Code of Russian Soviet Federative Socialist Republic, November 11, 1922 [Grazhdanskij kodeks Rossijskoj Sovetskoj Federativnoj Socialisticheskoj Respubliki ot 11.11.1922].

${ }^{23}$ Decree of the Soviet Government "About the order of distribution of nationalized and municipalized buildings and about the order of their use", November 30, 1925 [Dekret Soveta Narodnyh Komissarov ot 30.11 .19250 poryadke raspredeleniya nacionalizirovannyh i municipalizovannyh zdanij i poryadka ih ispol'zovaniya].

${ }^{24}$ Decree of the Soviet Government "About the increase of living space by using private capital for building", December 8, 1924 [Dekret VCIK, SNK RSFSR ot 08.12.1924 Ob uvelichenii zhiloj ploshchadi putem privlecheniya k stroitel'stvu chastnogo kapitala].

${ }^{25}$ Decree of the Soviet Government "About the right to use additional living space", September 29; 1924 [Dekret VCIK i SNK RSFSR ot 29.09.1924 O prave pol'zovaniya dopolnitel'noj zhiloj ploshchad'yu].

${ }^{26}$ Radaev and Schkaratan, Social Stratification, 46.
} 
The period of the new housing policy offically ended in 1926 when new purchase and sale regulations were adopted. It was prohibited by the new norm in criminal law. ${ }^{27}$ The purchase and sale of municipalized and nationalized urban apartments and rooms was punished by a monetary penalty of a maximum amount of up to five times the agreed price.

\section{Housing policies and the development of physical structure in Soviet cities: from industrialization to the Stalin era (1928 to 1953)}

Housing policy was strongly influenced by industrialization from 1928 to 1953 . The first five-year plan was adopted by the Fifth National Congress of Soviets of the Soviet Union in May 1928. The plan continued from October 1928 to October 1932 and represented a list of economic goals. One of the goals was to develop the Soviet Union from an agrarian country to an industrial one.

The prime goal was the development of the industry. The building of new and developing existing cities in the USSR was geared to the needs of the enterprises and new strategies in city development were discussed. At this time, Russian cities were described as 'Soviet' or 'socialistic' cities. A Soviet city was 'a centralized estate with a mono functional area structure. The population density of the residential districts was strictly controlled and the social infrastructure was standardized'. ${ }^{28}$

One of the central ideas in the first years of industrialization was a destruction of the historically formed differences between town and country. In this context, the British visionary Ebenezer Howard's concept of the 'garden city $^{29}$ was very popular. Because of the main economic goal, some authors propose as a midpoint stage in the development process. Miljutin and his colleagues worked out a programme for a zoned city that would have to build according to the conveyor belt principle. Miljutin describes this idea in his book 'Sozgorod', which was very famous in Russia and was translated into other languages. In accordance with this principle, the factories should have been built in one line. Traffic, shops, stores, infrastructure, and apartments should have been built in the next lines. These lines were isolated from the industrial zone through green spaces, a minimum of $500 \mathrm{~m}$ wide. This conveyor belt principle cared first for the high productivity of labour but not for the development of the social environment. The labour force should be living near the factories to have the shortest way to their work.

This idea was suitable for small towns and mono-industrial settlements. Generally, this principle was implemented in the industrial areas of big cities. Miljutin describes individual projects for Stalingrad, Magnitogorsk and Niznhy Novgorod in his book 'Sozgorod'. Moreover his idea was implemented in many Soviet industrial settlements like Novosibirsk ${ }^{30}$ as well as cities of Ural and Kuznetsk Basin and many Ukrainian cities. ${ }^{31}$ The conveyor belt principle became an inherent part of the Soviet planning praxis. There were two 'basic plans': The first, practiced from the 1950s to the 1960s, consisted of a 'linear arrangement: the sectors are stretched out along a single line'; the second was a 'circular arrangement: the sectors form a closed ring with an open space in the center'. ${ }^{32}$

The ecological structure of Soviet cities was different to those of Europe and North America: Ivan Szelenyi ${ }^{33}$ stated that it was not the old European pattern, the North American pattern, or a passing

\footnotetext{
${ }^{27}$ Decree "About the supplement of the criminal law of RSFSR with the article 135-A", August 9, 1926 [Dekret Vserossijskogo CIK i SNK RSFSR ot 09.08.1926 O dopolnenii Ugolovnogo kodeksa RSFSR stat'ej 135-a].

${ }^{28}$ Belkina, "Strategic Plans," 56.

${ }^{29}$ Howard, "Garden Cities of Tomorrow."

${ }^{30}$ Kosenkova, "Work on the Planning," 211-14.

${ }^{31}$ Botscharov and Han-Magomedov, Nikolay Miljutin, 32.

${ }^{32}$ Gutnov et al., The Ideal Communist City, 98-9.

${ }^{33}$ Szelenyi, Urban Inequalities.
} 
phase in a transition from one of those to the other. The West-European model means that the social status of the residents was higher in the city centre and lower in the periphery of the city (where the so-called slums were built). The English and North American cities 'often reversed it altogether with status rising from central slums to arcadian other suburbs. ${ }^{34}$ While the relationship between social status and the distance from the centre have linear character in the Western European and North American countries, the ecological structure in the building of Soviet cities was of a 'new kind' and can be described as follows:

The social status of the city centre declines somewhat, chiefly because of its declining residential numbers. The social status of the transitional zones declined rather faster. There is then high status in the new housing estates, but low status again in the rest of the outer suburbs. Of the two zones of low status, the deteriorating transitional zones are not yet entirely reduced to slums, so that the lowest social status of all is in the outer suburbs, even if physical housing conditions and 'housing satisfaction' are not so bad there. ${ }^{35}$

The view of the special ecological structure of Soviet cities is very plausible. However, the poor areas cannot be described as 'slums' in the conventional sense because of luck of the poor unemployment social group leaved in this urban area. Furthermore, 'no district was socially exclusive, the intelligentsia more frequently lived in the centre, while the outer districts had a larger share of artisans'.

Firstly, the apartment block level comprised 'relatively large and homogeneous areas in the socialist cities'. ${ }^{37}$ This arose because the 'urban inequalities were very greatly reduced under socialism' ${ }^{38}$ Secondly, the resident homogeneity was higher within the 'workers' outskirts' than within the downtown areas.

During the 1920s, the question of cottages vs. apartment houses was discussed. ${ }^{39}$ In 1927, the government recommended the building of apartment houses with rooms including kitchen, bathroom, living room, and so on, which have to be used by all parties in the house; ${ }^{40}$ so-called 'communal blocks of flats'. ${ }^{41}$ This living concept internalized the idea of a commune.

The Central Executive Committee of the Soviet Union ${ }^{42}$ outlined that housing and rental co-operatives managed 53 million $\mathrm{m}^{2}$ of living space and the housing and building co-operatives had a budget of 1.5 billion roubles. The main argument against housing co-operatives was that they were apartments built, for the most part, with the support of long-term (up to 60 years) state loans. It means that these apartments could stay in the ownership of the members; neither the government nor the municipality had any influence on the management of these buildings. As the Central Executive Committee of the Soviet Union (1937) ${ }^{43}$ explained the shareholders of the cooperation get apartments on the state's account for an unlimited period and for a non-repayable use; they became privileged owners of living space with just a negligible investment of their own means.

\footnotetext{
${ }^{34}$ Ibid., 147.

${ }^{35}$ Ibid., 147-8.

${ }^{36}$ Smith, The Socialist City, 82.

${ }^{37}$ Ibid., 96.

${ }^{38}$ lbid.

${ }^{39}$ Bylinkin et al., History of Soviet Architecture, 36-40.

${ }^{40}$ Decree "About the regulation of housing building which will be realized by executive committees, state institutions, and co-operatives", March 19, 1927 [Postanovlenie EHkonomicheskogo soveshchaniya RSFSR ot 19.03.1927 O regulirovanii zhilishchnogo stroitel'stva, osushchestvlyaemogo ispolnitel'nymi komitetami, gosudarstvennymi uchrezhdeniyami i kooperaciej].

${ }^{41}$ Andrusz, "Housing and Urban Development," 115.

${ }^{42}$ Decree of Central Executive Committee of Soviet Union "About the maintenance of housing stock and housing economy in the cities", October 17, 1937 [Prstanovlenie CIK SSSR i SNK SSSR ot 17.10.1937 O sohranenii zhilishchnogo fonda i uluchshenii zhilishchnogo hozyajstva v gorodah].

${ }^{43}$ lbid.
} 
According to the decree 'About the Maintenance of Housing Stock and Housing Economy in the Cities', housing and rental co-operatives were disestablished and all apartment houses given over to the municipalities or enterprises which built these houses from the fund for improving the everyday life of workers and salaried staff. Moreover, the apartment houses which were built by housing and building co-operatives were given over to the municipalities or enterprises in cases when the building of these houses was supported by state building loans or the enterprises. The apartments and houses could stay in private property only in the case of private financing.

It was described by several authors, that in the 1930s to 1950s, the social order was oriented to the development of monumental architectural forms according to the needs of the mass epic mind. ${ }^{44}$ Some comfortable apartments were also built during this time. Because most of these houses were built during the regime of Josef Stalin (1927-1953) they were named 'stalinka'. A new building style developed - Stalinist empire style. ${ }^{45}$

Housing policies varied in old and new settlements. In the old cities, new apartments could not be built quickly and because of the rapid expansion of the cities, some villages around the city were counted in the urban area. As a result, some districts were built with one story, one - or two-family dwellings without running water and bathroom units.

After the Second World War (1939-1945), citizens had the possibility of buying or building their own dwelling house in the city or outside the city. ${ }^{46}$ However, the buildings couldn't be higher than two floors and includes a maximum of five living or bedrooms. The proprietors had to finance these changes by themselves and the houses could be used for an unlimited period.

\section{Housing policies and the development of physical structures in Soviet cities: from the Khrushchev era to developed socialism (1953 to 1980s)}

The period of 'developed socialism' is also called the era of stagnation. This period began with Leonid Brezhnev as head of state in 1964 and ended with the beginning of Perestroika in 1987. At the beginning of this period there were a lot of acquisitions: a lot of new houses were built; new universities were established; the first man to go to space, etc. It dominates the stability and high quality of life in comparison to the period after the Second World War. The social development of society stagnates in the last part of this period.

Two urbanization trends existed at this time. The first development trend concerned the reconstruction of destroyed industry, the development of new industry in general, especially in the eastern part of the country, because of the development of the new minerals reserves. In this way, new settlements were established. The second development trend concerned the growth of the cities through the annexation of rural areas on the borders of the cities until the 1960s and 1970s. The undeveloped areas and existing villages were added in this way and led to the expansion of the urban areas. From the 1960s and 1970s, the urban area could not grow outwards. Urbanization was progressed by increasing construction concentration.

A new idea was implemented in this period as a reaction to city growth, the group settlement. This idea was already developed in the 1930s as an agglomeration of cities and towns on an economic and

\footnotetext{
${ }^{44}$ Han-Magomedov, "Stalinist Empire Style," 17; Ryabushin and Smolina, "The Avant-Garde," 11.

${ }^{45}$ Han-Magomedov, "Stalinist Empire Style."

${ }^{46}$ Decree of the Presidium of the Supreme Soviet of the Soviet Union "About the right of the citizens to buy and build individual dwelling houses", August 26, 1948 [Ukaz Prezidiuma Verhovnogo Soveta SSSR ot 26.08.1948 O prave grazhdan na pokupku i stroitel'stvo individual'nyh zhilyh domov].
} 
territorial basis. ${ }^{47}$ The idea of group settlement allowed the development of industrial zones and living areas with respect to its ecological makeup and landscape characteristics. The agglomeration could also link multiple cities, in which case it was called a multi-centered agglomeration. There were 14 multi-centered agglomerations in $1982^{48}$ : one of them was developed around Moscow and incorporated 19 cities; the next one was developed around Donetsk with 17 cities, and one of the youngest agglomerations developed around Kuznetsk and incorporated eight cities.

The main task of Soviet policy in the 1950s was the improvement of living conditions and people's affluence. During the Khrushchev era (1953-1964), the motto was 'each family - one apartment'. It was decided to minimize the costs of building new apartment houses with the objective of building as many separate apartments as possible. ${ }^{49}$ For this reason, new standard designs were drafted until 1 September 1956. It was also determined 'to begin planning economical comfortable apartments for single families in apartment houses in urban and rural areas in $19588^{\prime 50}$ The basis for the house building was a standard design with large-panel constructions. Four to five stories in the cities were recommended and two to three stories in the country. ${ }^{51}$ The best construction projects for houses for one-family apartments were chosen by national contest in $1956 .{ }^{52}$ Such apartment houses were developed and built in the period of governance by Nikita Khrushchev. For this reason, such houses are called 'khrushchovka'.

The idea of living areas called 'micro districts' (mikroraion, micro-region) was developed in Soviet architecture at the beginning of the 1930s and was first implemented in the 1950s. During the planning of the new micro-districts, there was an attempt to take account of the natural landscape. It removed the principle of symmetry that dominated the building of residential areas.

Since the middle of the 1960s, apartment houses with improved living conditions were planned. ${ }^{53}$ Moreover, after about 20 years of prohibition, the housing co-operative model was again established. In addition, the idea of increasing the density of the urban areas was implemented by building of the 'high-rise residential blocks' which allow 'the creation of an efficient system of services' ${ }^{54}$

Decisions regarding the settlement and moving of citizens was made in the period after the Second World War, and was completely in the state's hand. The government guaranteed the need for housing as a basic right, firstly in the Constitution of the USSR from 1977. According to Article 44 of the Constitution, the state provided for the development of secure national and public housing stock, supporting co-operative and individual housing construction, a fair distribution of living spaces under social control, and low rental prices and public services.

\section{Housing policies and the development of modern Russian cities: post-Soviet collapse (the 1990s onwards)}

Two major characteristics of the modern Russian city are the liberalization of the market and the establishment of the real estate market. The first opened up the possibility for some citizens to

\footnotetext{
${ }^{47}$ Bylinkin and Ryabushin, Modern Soviet Architecture, 10.

${ }^{48}$ Ibid., 11.

${ }^{49}$ Decree of the Central Committee of the Communist Party of the Soviet Union and Council of Ministers of the Soviet Union "About the elimination of architectural extravagances in designing and planning", November 4, 1955 [Postanovlenie CK KPSS i Soveta Ministrov SSSR ot 04.11.1955 Ob ustranenii izlishestv v proektirovanii i stroitel'stve].

${ }^{50}$ Decree of the Central Committee of the Communist Party of the Soviet Union and Council of Ministers of the Soviet Union "About the development of house building in the USSR", July 31, 1957 [Postanovlenie CK KPSS i Soveta Ministrov SSSR ot 31.07.1957 O razvitii zhilishchnogo stroitel'stva v SSSR].

${ }^{51}$ Ibid.

${ }^{52}$ Bylinkin and Ryabushin, Modern Soviet Architecture, 78.

${ }^{53}$ Smith, "The Socialist City," 86.

${ }^{54}$ Gutnov et al., The Ideal Communist City, 69-70.
} 
make money as it was possible to buy and sell most public objects. As a consequence of this most industry was privatized. These decisions engendered increasing differences in the socio-economic status of several social groups and regions. The second characteristic influenced the rise of residential mobility. Families with a high socio-economic status could buy new apartments or land and build a house.

Since the 1990s Russian cities are in economic competition with each other because of the development of the free market. Soviet city development was based on the principle that every city was built around a specific industry. Numerous settlements were planned as mono-industrial administrative units which led to clear economic differences between the cities and partly between the regions in the 1990s. In contrast to the Soviet period, the new strategic initiatives helped to enhance the scientific, technical and intellectual potential of the cities and regions with the acceptance of market mechanisms. ${ }^{55}$ Socio-economic inequality arose between and within regions. The industrial technology in some cities became obsolete as the products once produced were no longer competitive. Consequently, the unemployment rate increased in parallel with decreasing lifestyle quality, and the socio-economic status of the population worsened. This situation affected most small monoindustrial towns that were located far away from regional centres.

The government already saw the problem of the mono-industrial towns ('monogorod') in the first years after the collapse of communism. However, it took a long time before the first supporting programmes were established. The term 'monogorod' consists of two parts: 'mono' (single) and 'gorod' (city); it is also an abbreviation of 'city with a mono specialization'. Monogorod are named mostly 'satellite city/town' or 'monocity/town'. The monotowns are urban settlements whose economic base was dominated by a single industry or core enterprise.

In the early 1990s, they were defined in terms of settlements with a minimum of $30 \%{ }^{56}$ of the population working at the same enterprise. The core enterprise was not fixed at this time. In 1998 , it was defined as an enterprise with a number of employees at a minimum of $50 \%$ including their relatives. ${ }^{57}$ Some years later, in 2002, the new Federal Law defined core enterprises as a legal person with a number of employees which was a minimum of $25 \%$ of the able-bodied population of the relevant settlement. ${ }^{58}$

In summary, the socio-economic situation of the cities depends on their size, function, and geographical position within a given region. ${ }^{59}$ The smaller the settlement, the higher the unemployment rate, the lower the salary, and the trade turnover. The economies of medium-sized and small towns are bigger when the latter are near megalopolises or other cities. Additionally, the economic situation is better in medium and small towns when there are local oil or gas industries, energy centres, or towns with foreign capital, or export production.

In contrast to the situation in Soviet Russia when there was an attempt to eliminate natural segregation processes in terms of ecological research of the Chicago School, these processes began in the 1990s with the establishment of the real estate market. In the Soviet period most apartments were

\footnotetext{
${ }^{55}$ Klewakin, Siberian City, 23-4.

${ }^{56}$ Order of the Government of Russian Federation "About the order of the definition of core enterprises and sale features for insolvent core enterprises", August 29, 1994 [Postanovlenie Pravitel'stva RF ot 29.08.1994 O poryadke otneseniya predpriyatij k gradoobrazuyushchim i osobennostyah prodazhi predpriyatij-dolzhnikov, yavlyayushchihsya gradoobrazuyushchimi].

${ }^{57}$ Federal Law "About insolvency", No. 6-FZ, January 8, 1998 (expired) [Federal'nyj zakon ot 08.01.1998 N 6-FZ O nesostoyatel'nosti (bankrotstve) (utratil silu)].

${ }^{58}$ Art. 169 of the Federal Law "About insolvency", No. 127-FZ, October 26, 2002 [Federal'nyj zakon ot 26.10.2002 N 127-FZ O nesostoyatel'nosti (bankrotstve)].

${ }^{59}$ Nefedova, "Russia's Periphery," 16-8; Nefedova and Treyvish, Cities and Rural Areas; Nefedova and Treyvish, "Russian Cities"; Alexandrova et al., "What can be Learned."
} 
governmental or municipal property and were rented on a permanent basis to families. The new law $^{60}$ established the main principles of exercising the privatization of state and municipal housing stock in Russia. The first principle was that every citizen has the right to become the owner of living accommodation in governmental or municipal buildings without charge, by privatization, and only once (Art. 11). This law defines the legal, social and economic basis for the transformation of ownership relations with respect to the housing. The goal of this statute was the establishment of terms and conditions to realize human rights for free choice to satisfy a want for housing and to improve the utilization and safety of housing stock. From 1 October 1992, the privatization of enterprises with privatization vouchers was enabled. ${ }^{61}$

Private property owned by citizens in cities decreased between 1970 and 1990 from 23.7\% to $15.1 \%$. From the beginning of the 1990 s, renters could also privatize, buy, or sell apartments and many families did so. The rate of ownership doubled in 1995 (33.8\%). 50.6\% of urban living accommodations was privatized by citizens by 2000 , and by $70.2 \%$ in $2005,80.2 \%$ in 2010 , and $83.6 \%$ in $2014 .{ }^{62}$

\section{Discussion and outlook}

The first few years of the Soviet country were accompanied by the ruination of the economy and building environment. The new government did not have a house building plan. The housing policy consisted of the nationalization of land, nationalization and municipalization of buildings, and redistribution of existing living space.

Gregory Andrusz pointed out that the Soviet housing model 'lost its place on the economists' agenda and became an ideological issue'. ${ }^{63}$ The latter consists of four special features:

(i) there is a limited housing market, with (ii) a stable rental charge for accommodation, which (iii) comprises an insignificant portion of the family budget and, (iv) under these circumstances the process of distributing (raspredelenie) accommodation takes place as a dispensing (razdacha) of flats either at the place of work or place of residence. ${ }^{64}$

This arrangement could be expected to have the following consequences: (i) to iron out housing inequalities by substantially reducing differences in the supply of housing to different strata in the population;

(ii) to compensate for income inequalities; (iii) to guarantee equal access to housing, as laid down in the Constitution. ${ }^{65}$

Both kinds of segregation (social and spatial) were also strictly controlled during the Soviet period. As a result, the socio-economic heterogeneity was higher between, than within, the cities. With respect to neighbourhoods, because self-selection rarely took place in Soviet Russia, homogeneity was low within and high between neighbourhoods. Only central districts occupied by nomenclatura were more homogeneous with respect to socio-economic variables. The physical structures of new industrial cities were very homogeneous because of the absence a downtown area. A downtown and old buildings contributed to more heterogeneity in the older historically developed cities.

\footnotetext{
${ }^{60}$ Federal Law "About privatization of housing stock in Russian Federation", No. 1541-1, July 4, 1991 [Zakon RF ot 04.07.1991 N 1541-1 0 privatizacii zhilishchnogo fonda v Rossijskoj Federacii].

${ }^{61}$ Decree of the President of the Russian Federation "About the establishment of privatization vouchers' system in the Russian Federation", August 14, 1992 [Ukaz Prezidenta RF ot 14.08 .920 vvedenii v dejstvie sistemy privatizacionnyh chekov v Rossijskoj Federacii].

${ }^{62}$ Federal Office of the State's Statistics, Russian statistic yearbook; Siegmunt, Selbstkontrolle, 72.

${ }^{63}$ Andrusz, "A Note on the Financing," 556.

${ }^{64}$ Ibid.

${ }^{65}$ Ibid.
} 
The major characteristics of Russian society after the social collapse are the development of the real estate market, as well as the rise of residential mobility and of residential segregation. Because of the liberalization of the market, the socio-economic situation changed for the worse, in particular, for the small mono-industrial cities and towns. Social homogeneity was higher there than in the big cities with several industries and sometimes with a favourable geographical position. Because of the free real estate market a large number of people bought apartments and houses and changed their place of residence. In this way, inhabitants with a similar socio-economic or demographic background lived in the same neighbourhoods. The differences between the urban districts increased because of the natural migration processes on the one hand and because of the socio-economic inequality of the population on the other hand.

A lot of books and articles were published about the Soviet urban planning, housing system, and housing policy. Most of them were published in the 1970-80s during the existence of the USSR or in the 1990s directly after its social collapse. Ivan Szelenyi wrote more than 30 years ago:

I think we are ready to begin to test these hypotheses [inequalities in housing allocation, and the degree and patterns of residential segregation] in a systemic way. We may need to generate more survey data for cross-national comparison ... from various communist (and for that sake, non-communist) countries with a common theoretical frame and with the same methodology. ${ }^{66}$

Currently, communist countries no longer exist; but the post-communist countries with their planning history do.

We accepted Szelenyi's challenge a few years ago by seeking to identify the different results in Russian cities within the framework of the social disorganization theory. The provided study of neighbourhoods in Russian cities ${ }^{67}$ represented the results of the analysis of the ecological effects of neighbourhoods on the basis of the social disorganization theory by Shaw and McKay with the help of the survey data from three Russian cities. Some results of this study were discussed at international criminological conferences. ${ }^{68}$ This article is the first step towards a systematic description of the historical development and housing policy of Russian cities. Its objective is to understand our first results. ${ }^{69}$

A social disorganization theory was developed on the basis of observations in Chicago and other US American cities during the urbanization in the 1920s. We tested the main hypotheses of the theory in a total of 193 Russian neighbourhoods. The premise of a good theory is that it is valid every time and in every society. Among other things, it was examined as to whether exogenous structural characteristics of the neighbourhoods like poverty, ethnic heterogeneity, residents mobility and incomplete families cause the social disorganization in the neighbourhoods, which was operationalized as social cohesion. However, some results of the testing of this theory were different to those obtained in US cities. It was assumed that all these exogenous structural characteristics influence social cohesion in the following ways: the higher the level of poverty, ethnic heterogeneity, residential mobility, and proportion of incomplete families are in particular neighbourhoods, the weaker is the social organization there. Poverty was operationalized here as socio-economic status (SES) of the families. In contrast to the theoretical assumptions, (1) social cohesion in neighbourhoods was higher when the socio-economic status of the neighbourhoods was low; (2) ethnic heterogeneity had no effect on the neighbourhood level at all.

\footnotetext{
${ }^{66}$ Szelenyi, "Housing Inequalities," 7-8.

${ }^{67}$ Siegmunt, Selbstkontrolle; Siegmunt, Neighborhood Disorganization; Siegmunt, "Mediating Role".

${ }^{68}$ Siegmunt, "Is the Theory"; Siegmunt, "The Historical Development."

${ }^{69}$ Siegmunt, Selbstkontrolle; Siegmunt, Neighborhood Disorganization; Siegmunt, "Mediating Role."
} 
The first finding was explained as follows:

Perhaps the key to explaining this result in the understanding of what constitutes substantive meaning of the SES, is mainly based on the parental educational background. However, it is plausible to assume that residents with a high level of education have more contacts outside their neighbourhoods. Accordingly, there should also be less need for emotional bonding within the neighbourhoods. This interpretation is not necessarily particular to the Russian cases. For Russia a specific interpretation could be that present historical reasons mainly explain that people with higher SES in developing areas with comfortable apartments draw in which social cohesion is still in a developing phase. ${ }^{70}$

The second finding can be explained by the strict urban planning of the Soviet cities and controlling of population distribution. As a result of the latter, residents' self-selection was almost impossible. This situation leads to high homogeneity between and low homogeneity within neighbourhoods. The political and economic situation in Russia also affected social and spatial residential segregation.

The main goal of this paper has been to show how the systematic development of Soviet and Russian law in some parts of housing policy has been the basis for spatial and social segregation in the cities. This methodological apporach, as well as the interdisciplinary perpective on the modern Russian cities' problems are relatively new for this field of knowledge. This paper connects material from official documents and the historical periods of country development to offer a plausible explanation of the situation in which the social disorganization theory does not work according to its generally held assumptions. It constitutes an initial approach to understanding the results of the empirical testing of the social disorganization theory in Russia with the historical methods.

\section{Disclosure statement}

No potential conflict of interest was reported by the author.

\section{Notes on contributor}

Olga Siegmunt is an associate professor at the Department of Deviantology and Criminology on the Law Institute of the Siberian Federal University, Russia, and a lecturer for criminology and research at the University of Vechta, Germany. Her research interests are essentially survey research, international comparative studies, juvenile delinquency, ecology of crime, and crime geography. Dr Siegmunt serves in the editorial board of the journal 'Legal Science and Law Enforcement Practice'. She has also worked as a consultant for criminological research in the State Office for Criminal Investigation of Lower Saxony, Hanover, Germany.

\section{Bibliography}

Alexandrova, A., E. L. Hamilton, and P. Kuznetsova. "What Can be Learned from Introducing Settlement Typology into Urban Poverty Analysis: The Case of the Tomsk Region, Russia." Urban Studies 43, no. 7 (2006): 1177-1189.

Andrusz, G. "Some Key Issues in Soviet Urban Development." International Journal of Urban and Regional Research 3, no. 2 (1979a): 157-180.

Andrusz, G. "Urban Government: A Focal Issue on Studies on the Russian and Soviet City: A Book Review." International Journal of Urban and Regional Research 3, no. 4 (1979b): 553-565.

Andrusz, G. Housing and Urban Development in the USSR. London [u.a.]: Macmillan Press, 1984.

Andrusz, G. "The Built Environment in Soviet Theory and Practice." International Journal of Urban and Regional Research 11, no. 4 (1987): 478-499.

\footnotetext{
${ }^{70}$ Siegmunt, Neighborhood Disorganization, 71.
} 
Andrusz, G. "A Note on the Financing of Housing in the Soviet Union." Soviet Studies 42, no. 3 (1990): 555570.

Andrusz, G. "Structural Change and Boundary Instability." In Cities after Socialism: Urban and Regional Change and Conflict in Post-Socialist Societies, edited by Gregory Andrusz, Michael Harloe, and Ivan Szelenyi, 30-69. Cambridge: Blackwell Publishers, 1996.

Andrusz, G. "Berlin, Moscow, Warsaw: A Century of Sibling Rivalry Expressed in Urban Form." Urban Research and Practice 1, no. 2 (2008): 181-198.

Bater, J. H. St Petersburg: Industrialization and Change. London: Edward Arnold, 1976.

Bater, J. H. The Soviet Scene: A Geographical Perspective. London [u.a.]: Edward Arnold, 1989.

Bater, J. H. Russia and the Post-Soviet Scene. London: Arnold, 1996.

Belkina, T. D. "Strategic Plans of City Development and Tools for their Implementation [Strategicheskie plany gorodskogo razvitiya i instrumenty ikh realizatsii].” Probleme der Prognostizierung 3 (2010): 55-72.

Bessonova, O., S. Kirdina, and R. O'Sullevan. Market Experiment of the Russian's Edit-Economy: Show Projects in the Housing Industry [Rynoznyi eksperiment v razdatoznoy ekonomike Rossii: demonstrazionnye projekty v ziliznom hozjaystve]. Novosibirsk: Novosibirsk University Press [in Russian], 1996.

Botscharov, J. P., and S. O. Han-Magomedov. Nikolay Miljutin [Nikolai Miljutin]. Moscow: Architectura-S [in Russian], 2007.

Bylinkin, N. P., W. N. Kalmykowa, A. W. Ryabushin, and G. W. Sergeewa. History of the Soviet Architecture, 1917-1954 [Istoriya sovetskoy arkhitektury, 1917-1954 gg.]. Moskau: Stroyizdat, 1985.

Bylinkin, N. P., and A. W. Ryabushin. Modern Soviet Architecture, 1955-1980 [Sovremennaya sovetskaya arkhitektura, 1955-1980]. Moskau: Stroyizdat, 1985.

Davidow, M. Cities Without Crisis. New York: International Publishers, 1976.

Decrees of Soviet Rule. Volume I, Moscow: Gos. izdatelstvo polit. Literatury, 17-20, 1957.

Direction of the Central Department of the Communal Services by the Government of RSFSR Nr. 64 from April 7th, 1931. Newalatter of the FHZ, 17, 43-45.

Federal Office of the State's Statistics, eds. Russian Statistic Yearbook [Rossiyskiy statisticheskiy ezhegodnik]. Moscow: Rosstat, 2003-2015.

Friedrichs, J. "Large Cities in Eastern Europe." In The Metropolis Era. Vol. 1. A World of Giant Cities, edited by Mattei Dogan and John K. Kasarda, 128-154. Newbury Park, CA [u.a.]: Sage, 1988.

Gerasimova, E. "Soviet Communal Apartment [Sovetskaya kommunal'naya kvartira]." Sotsiologicheskij Zhurnal 1-2 (1998): 224-243.

Gutnov, A., A. Baburov, G. Djumenton, S. Kharitonova, I. Lezava, and S. Sadovskij. The Ideal Communist City. New York: George Braziller, 1968.

Hamm, M. F., ed. The City in Russian History. Kentucky: The University Press of Kentucky, 1976.

Han-Magomedov, S. Architecture of the Soviet Avant-Garde [Arkhitektura sovetskogo avangarda]. Vol. 2: Social problems [Sotsial'nye problemy]. Moscow: Stroyizdat, 2001. http://www.alyoshin.ru/Files/publika/ khan_archi/khan_archi_2_000.html.

Han-Magomedov, S. “'Stalinist Empire Style’: Problems, Tendencies, Masters ['Stalinskiy ampir': problemy, techeniya, mastera]." In Architecture of the Stalin Era: Experiences of the Historical Understanding [Arkhitektura stalinskoy epokhi: opyt istoricheskogo osmysleniya], edited by J. L. Kosenkova, 10-24. Moscow: KomKniga, 2010.

Howard, E. Garden Cities of to-Morrow. London: S. Sonnenschein \& Co, 1902.

Kashkadamov, V. Sanitary Control of the Living Accommodations [Sanitarnaya okhrana zhilishch]. 2nd ed. Moscow: Narkomzdrav, 1920.

Klewakin, A. N. Siberian City During the Transformation Era [Sibirskiy gorod v epokhu peremen]. Nowosibirsk: Nauka, 2008.

Kosenkova, Y. L. "Work on the Planning Projects of Novosibirsk in the 1920s-1930s [Rabota nad proektami planirovki Novosibirska v 1920-1930-e gody].” In Soviet Town Planning in the 1920-1930s: New Research and Materials [Sovetskoe gradostroitel'stvo 1920-1930-h godov: Novye issledovaniya i materialy], edited by Y.L. Kosenkova, 202-229. Moscow: Knizhnyy dom LIBROKOM, 2010.

Lenin, V. I. Supplements for the Draft of the Decree about the Requisition of Thick Clothing for the Solders on the Front, Written in November 8 (21), 1917 (p. 380) [Dopolneniya k proektu dekreta o rekvizicii teplyh veshchei dlya soldat na fronte]. Complete Edition [Polnoe sobranie sochineniy]. Issue 54. Moscow: Izdatelstvo politizeskoy literatury, 1975. 
Lipsiz, I. V. Monotowns and Core Enterprises. Review Report. [Monoprofilnye goroda i gradoobrazujuzie predprijatija. Obzornyi doklad.] Vol. 1. Moscow, 2000.

Luzenko, N. M. Housing Problem and Housing Policy in the USSR [Zhilishchnaya problema i zhilishchnaya politika v SSSR]. Moscow, 1972.

Meerovitsch, M. Punishment by Living Accommodation: Housing Policy in the USSR as Instrument for Direction of People (1917-1937) [Nakazanie zhilishchem: zhilishchnaya politika v SSSR kak sredstvo upravleniya lyud'mi (1917-1937 gody)]. Moscow: Rossiyskaja politizeskaja enziklopedia, 2008.

Miljutin, N. A. Sozgorog. Probleme der Errichtung der sozialistischen Städte. Grundfragen rationalen Planung und Bau der Wohnorte in der UdSSR [Sotsgorod. Problemy stroitel'stva sotsialisticheskikh gorodov. Osnovnye voprosy ratsional'noy planirovki i stroitel'stva naselennykh mest SSSR]. Moskau - Leningrad: Staatlicher Verlag, 1930.

Nefedova, T. G. "Russia’s Periphery as a Socio-Economic Phenomenon (Rossiyskaja pereferija kak sozialnoekonomizeskiy fenomen).” Regional Studies 5, no. 20 (2008): 14-30.

Nefedova, T., and A. Treyvish. "Cities and Rural Areas: Status and Relationship within the Russia [Goroda i sel'skaya mestnost': sostoyanie i sootnoshenie v prostranstve Rossii]." Regionale Studien 5, no. 20 (2010a): 42-57.

Nefedova, T., and A. Treyvish. "Russian Cities Before the Last Crisis: Increase of the Spatial Differences [Goroda Rossii do poslednego krizisa: narastanie prostranstvennykh razlichiy].” Demoskop Weekly, 437/ 438, 2010b. http://demoscope.ru/weekly/2010/0437/tema03.php.

Park, R. E. "The City: Suggestions for the Investigation of Human Behavior in the Urban Environment." In The City, edited by R. E. Park, E. W. Burgess, and R. D. McKenzie, 1-46. Chicago [u.a.]: The University of Chicago Press, 1925.

Park, R. E., and E. W. Burgess. Introduction to the Science of Sociology. Chicago [u.a.]: University of Chicago Press, 1969 [1921].

Park, R. E., E. W. Burgess, and R. D. McKenzie. The City. Chicago [u.a.]: The University of Chicago Press, 1970 [1925].

Radaev, V., and O. Schkaratan. Social Stratification [Sotsial'naya stratifikatsiya]. Moskau: Nauka, 1995.

Ryabushin, A., and N. Smolina. "The Avant-Garde of the Twenties." In Landmarks of Soviet Architecture 19171991, edited by Vieri Quilici, 9-25. Berlin: Ernst \& Sohn, 1992.

Shaw, C. R., and H. D. McKay. Juvenile Delinquency and Urban Areas. Chicago \& London: University of Chicago Press, 1972 [1942].

Siegmunt, O. Selbstkontrolle: Einflüsse von Familie, Schule und Nachbarschaften. Eine kontrolltheoretische Studie in drei russischen Großstädten. Berlin: Wissenschaftlicher Verlag Berlin, 2012.

Siegmunt, O. "Is the Theory of Social Disorganization by Shaw and McKay Valid in Russia?" 14th Annual Conference of the European Society of Criminology, Prague, September 10th-13th, 2014.

Siegmunt, O. "Mediating Role of Social Disorganization: A Case Study of Russian Neighborhoods." Journal of Criminal Investigation and Criminology 66, no. 4 (2015): 342-352.

Siegmunt, O. Neighborhood Disorganization and Social Control: Case Studies from Three Russian Cities. Springer: Springer Briefs in Criminology, 2016.

Siegmunt, O. "The Historical Development of the Housing Policy as Well as the Social and Demographical Structure of Russian Cities and the Social Disorganization Theory by Shaw and McKay." 18th Annual Conference of the European society of Criminology, Sarajevo, Bosnia and Herzegovina, August 29th to September 1st, 2018.

Smith, D. M. "The Socialist City." In Cities after Socialism: Urban and Regional Change and Conflict in PostSocialist Societies, edited by Gregory Andrusz, Michael Harloe, and Ivan Szelenyi, 70-99. Cambridge: Blackwell Publishers, 1996.

Szelenyi, I. Urban Inequalities under State Socialism. New York: Oxford University Press, 1983.

Szelenyi, I. "Housing Inequalities and Occupational Segregation in State Socialist Cities." International Journal of Urban and Regional Research 11, no. 1 (1987): 1-8.

Vasil'ev, N. "The Short Period of the Architectural Leadership [Korotkiy period arkhitekturnogo liderstva]." Moskovskoe nasledie 18 (2012): 10-14. https://dkn.mos.ru/upload/iblock/767/mn18_.pdf.

Verezagina, T. A., and K. A. Trushkina. "About the Essence and Classification of the Monotowns [O suznosti i klassifikazii monogorodov]." In Problems and Perspectives of the Economy and Governance: Materials of the IV International Scientific Conference, 172-176. St. Petersburg: Svoe izdatelstvo, 2015. 